\title{
Land use changes and development of the non-forest woody vegetation in the Danubian Lowland in Slovakia
}

\author{
Ján Supuka*, Karol Šinka \\ Slovak University of Agriculture in Nitra, Faculty of Horticulture and Landscape Engineering, Tr. A. Hlinku 2, SK-949 76 Nitra, \\ Slovak Republic
}

\begin{abstract}
The aim of this paper is to assess the changes in the landscape structure of the Žitný Ostrov territory and in the woody species of the non-forest woody vegetation (NFWV) over the past 120 years. Within the assessed periods of 1892 , 1949, 1969 and 2015, the shares of arable land increased by 17\% while the ratio of the built-up areas with gardens increased by $3.7 \%$. At the same time, natural habitats, grassland, waterlogged meadows and wetlands decreased by $26 \%$. These changes, concerning small mosaic plots as well as large cultural blocks, were caused by the intensification of agriculture after 1948. Ecological stability and biodiversity of these areas has decreased. Thereafter 60 windbreaks were planted from 1951-1952 in an area of 30 ha. In total, 37 woody species were planted, of which 22 were alien species. After 25 years (in 1976), 19 of the same windbreaks were surveyed, observing 16 native and 12 alien woody species. During these periods, many rare alien and coniferous species died. In 2015, 13 windbreaks with 39 woody species were identified, both in the tree and the shrubby layer. The downside is that four of the long-time surviving species are invasive trees.
\end{abstract}

Key words: landscape structure changes; windbreaks; woody species; long-term monitoring

Editor: Bohdan Konôpka

\section{Introduction}

Geography and ecology potential, land-use forms and land ownership represent the basic criteria for the cultural landscape assessment and design (Kupka 2010; Verešová \& Supuka 2012; Kuča et al. 2015). Land use changes are projected into historical and current landscape structure in composition, size and distribution of landscape elements in landscape image, as well as character in its cultural and perceived values (Hernik 2009; Agnoletti et al. 2010; Supuka et al. 2011). Pucherová (2004) published the results of landscape structure development and changes in five studied cadastral territories of Nitra suburbs in the time horizons of 1863,1892, and 2002. By comparison of historical and current landscape structure, the author has identified a $10-30 \%$ decreasing share of landscape elements significant for ecological stability. This group includes forests, non-forest woody vegetation, permanent grassland, old traditional fruit orchards, and mosaic small size plots. However, there was an increase of large blocks of arable land, intensive fruit orchards, and new established water basins. The structural changes in the category of vineyard landscapes were assessed in studied territories of Slovakia in the cadastre Čajkov, Nitrianske Hrnčiarovce in Nitra vineyard region (Verešová \& Supuka 2013), the traditional Small Carpathian vineyard region (Štefunková et al. 2011), as well as in the Bavaria vineyard region in Germany (Petit et al. 2012). Emphasis was given to landmark changes and their cultural and historical values for potential recreation use as well (Cieszewska et al. 2010).

Structural changes of the agriculture landscape in Slovakia with regard to the identification of historical structure elements and their changes were published by Špulerová et al. (2011). In the same way, landscape structure changes and development in the Podoubraví region in the Czech Republic were assessed (Lipský et al. 2011). Land use and land cover changes in China and the United States over the past 300 years were compared. A noticeable trend was the increase in croplands and decrease of the forest and grassland / shrub land areas in both USA and China, however, in different proportions. Larger areas of decrease were found in China, since the United States is a younger cultural country (Fanneng et al. 2015).

In the agricultural landscape structure, we shall work on the important assumption that the non-forest woody vegetation (NFWV) is an effective landscape ecological

*Corresponding author.Ján Supuka, e-mail:jan.supuka@uniag.sk 
stability element. Its share in the countryside is closely related to the historical development, changes in land-use forms, intensification of agriculture technologies, and land ownership (Pucherová 2004; Kupka 2010; Kuczman 2014). In the whole Slovakia, the share of non-forest woody vegetation in agriculture landscapes was defined as 5 to $12 \%$ depending on geography and relief conditions, land-use form and land cover (Supuka et al. 2013). In France, conditions were identified as a 5-15\% share of NFWV in agricultural landscape (Soltner 1991) per different phytogeographical conditions.

Important results were achieved in research of forest and windbreaks on biomass production and crop yields in agriculture landscape (Tutka 2010). The cumulative effectiveness of forest and windbreaks in distance by 100 and $150 \mathrm{~m}$ from forest margin caused yield increase of assessed crops by $7-15 \%$ depending on altitude, climate and soil characteristics. Stated value of agro-production forest function reaches $0.66-2.32 €$ year $^{1}$ ha $^{-1}$ according to the agro-climate regions of Slovakia (Tutka 2010).

The non-forest woody vegetation, as an important landscaping element with significant gene pool value, represents an old, oversized specimen of rare trees considered as elements of tree heritage (Morton 1998; Supuka \& Pucherová 2013; Demková \& Lipský 2017). In the lowland landscape of south-western Slovakia, woody species richness of Prunus genus in dispersed woody vegetation in the agriculture landscapes was surveyed (Baranec et al. 2011). In the protective forest belts on the territory of three forest units of the south-western Slovakia, 59 woody species were inventoried, including 19 native species (Varga et al. 1999). Great attention was payed to the identification and assessment of old fruit trees in the dispersed landscape vegetation. In Hriňová cadastre, 10 varieties were surveyed and in Hrušov cadastre, 13 varieties (Zrníková et al. 2014). The occurrences of Service Tree, Sorbus domestica, and Black mulbery, Morus nigra, as rare fruit trees were identified in 24 localities of agriculture landscape in NFWV elements (Paganová \& Bakay 2010) and also in traditional mosaic structure vineyards of Western Slovakia (Verešová 2011). Service Tree is richly present in the geographical territory of White Carpathy in South Moravia, where its specific varieties were identified in 12 localities (Tetera et al. 2006).

In the Alpine pastoral landscape, participation of line form NFWV elements including hedges, as well as their effectiveness in landscape image and biodiversity was studied (Kurz et al. 2011). Planning, establishment, and management of NFWV in the rural agricultural landscapes of Slovakia have been published by Tóth et al. (2016), while the situation in the Czech Republic was described by Salašová (2001).

The aim of this paper is to assess the landscape structure development within the last almost 120 years, with emphasis on spatial changes in the non-forest woody vegetation and its woody plant biodiversity.

\section{Material and methods}

The chosen study area was the Žitný Ostrov territory, which is a part of geographical unit Danubian Lowland in the south-western Slovakia. In this territory, woody species composition and space structure of chosen protective forest belts (windbreaks) has been compared in three time horizons of 1951, 1976 and 2015. Thanks to one published contribution (Gemerský 1961), we have acquired an original document about space distribution of 60 windbreaks that were established in agriculture landscapes in the years 1951-1952. Spatial distribution of windbreaks on the Žitný Ostrov territory, as well as case planting plans of applied woody species is documented by the originally published maps and plans. The list of planted woody plant species is composed of plants representing wide species diversity. Later in 1976, we surveyed the woody species and spatial composition at 19 chosen windbreaks in six cadastral territories of the Žitný Ostrov territory, Dobrohošt', Horný Bar, Bodíky, Hubice, Malá and Velká Paka. More particular investigation and assessment of the NFWV, their historical development, and the spatial distribution was provided in four time horizons (1892, 1949, 1969 and 2015). The assessment was accomplished on the landscape segments covering the cadastral territories of Dunajský Klátov (353.9 ha), Malé Dvorníky (747.6 ha), Velké Dvorníky (139.2 ha), Jahodná (110.0 ha), Vydrany (118.9 ha); in total 1968.03 ha. Assessed landscape structure development and changes between established time horizons were accomplished by using historical maps: III. Military survey and cadastral maps (1892), aerial photo $(1949,1969)$ and ortho photo maps. (Used sources: (C) Geodetic and Cartographic Institute Bratislava - GKU Bratislava, (C) Topographic Institute - TOPU Banská Bystrica and (C) National Forest Centre - NLC Zvolen).

Non-forest woody vegetation (NFWV) was assessed through comprehensive field surveying (2015) according to the following criteria: origin (natural, cultural, mixed), spatial formation (line, group, area), and functional type (road and water body accompanying, windbreak, grove, etc.). Woody species composition in NFWV was assessed according to the growth categories (tree, shrub, climbing), as well as the share of occurrence and abundance of the tree and shrubby layers separately (Supuka et al. 2013).

Woody species proportion according to origin was assessed in NFWV elements by modified index of synantropisation (Jurko 1990; Supuka et al. 2013) in the equation form:

$$
I S=\frac{N_{a}}{N_{n}}
$$

Where: $\mathrm{Na}$ - number of alien woody species; $\mathrm{Nn}$ - number of native species. 
Indexes were calculated for NFWV assessed in 1967 and 2015. The aim of this approach was to compare woody species changes and windbreak composition during a period of 60 years after they had been established.

From the terminology point of view, we should explain the differences in woody spatial formations. Windbreaks represent line form woody formations planted on lowlands with anti-wind erosion effect and climate mitigation. The term notion is used mainly in western literature sources, e.g. USA, UK, France (Insley 1988; Soltner 1991). Forest protection belts mean windbreaks and protective infiltration woody belts on slopes. Their main effect is wind and water anti-erosion. Notion is used mainly in forestry literature including Russian sources (Gemerský 1961; Varga et al. 1991; Tutka 2010). Nonforest woody vegetation (NFWV) includes all spatial woody formations in agriculture landscape, meaning linear forms (windbreaks, infiltration belts, accompanying belts along water streams and roads, tree alleys), area forms (small forests, groves, game refuges), and group and solitaire trees in rural landscape (Supuka et al. 2013; Demková \& Lipský 2017).

\section{Results}

\subsection{Assessment of the landscape structure development and changes at the Žitný Ostrov territory}

The plantings of the first windbreaks on the Žitný Ostrov territory in the south-western Slovakia was closely connected to socio-economic changes after the World War II. Changes in the agricultural landscape can be seen in size, proportion, and distribution of landscape elements in the territorial space. They were influenced by the economic development, production and processing technologies, demography, and human settlement development. The expressive change seen in the agricultural landscape in Slovakia in the second half of the 20th century was also influenced by the process of technological intensification and land ownership. An interesting experiment in 1949 was the establishment of a rice field on 24.77 ha in the rated landscape segments (see Fig. 3 and Table 1). The establishment of large cooperative farms in the lowlands started prior to 1949-1950, mainly in the lowlands Podunajská, Východoslovenská and Záhorská. These changes can be observed in the lack of small size mosaic plot structure, in alternation by large cultural blocks, the removal of many natural valuable biotopes, drainage of some wetlands, and the removal of terraced balks, banks and line borders between plots. In many cases, permanent grasslands and spatial elements of non-forest woody vegetation have decreased as well. Moreover, new water canals and damps were built. These landmark changes are reflected as new features in the compositional aesthetic characteristics and dimensions of the study areas.
The landscape ecological stability has decreased, as have culture-historical values and natural biodiversity. However, there was an increase in the cultural diversity of plant and animal varieties. The potential threat of water and wind erosion was increased. The landscape structure changes are generally seen in aerial photos of the country segment between 1949 and 1969 on the Žitný Ostrov territory (Fig. 1). Particular landscape structure changes and development within rated periods of 1892 , 1949,1969, and 2015 are presented on the attached maps (Fig. 2-5); the area share of landscape elements is given in Table 1.

The map and table show that in 1892, arable land was dominant, with more than $63 \%$ as the element of the cultural landscape and terra ferma. The second position belongs to natural elements of grasslands and waterlogged meadows used mostly as pastures. In total, these areas covered $29 \%$ of the assessed territory. These landscape elements should be considered as natural or near natural with high ecology and biodiversity benefits. The assessed lowlands were only $3.46 \%$ share of forest. This area had mostly alluvial character and involved predominating willow and poplar woody species. Colonization was quite low in the built-up areas at $1.42 \mathrm{ha}$, only because the landscape segment represented open rural country. The situation changed in 1949 , when there was a rapid reduction in the share of grasslands and waterlogged meadows used as pastures, only $4.85 \%$. There was an increase in the share of built-up areas and gardens. Water lines increased due to the wetland drainage and construction of the canals. An interesting experiment in 1949 was the establishment of a rice field on 24.77 ha in the rated landscape segments. When the countryside in 1949 and 1969 was compared, the landscape structure changed from small plot mosaics to larger cultural blocks of mainly arable land. The share of NFWV increased noticeably due to new plantings of windbreaks from 1951-1952 (Fig. 2, 3, 4; Table 1). The lands status between the period of 1969 and 2015 should be considered as relatively balanced in arable land, grassland and forest cover. The share of NFWV representing predominantly windbreaks has significantly increased and reached $6.56 \%$ in the rated landscape segment (Fig. 4,5).

\subsection{Assessment of the first windbreaks plantings at the Žitný Ostrov territory}

As described in the previous chapter, in order to eliminate and mitigate negative features and processes in the landscape, new windbreaks or protective forest belts were established as a part of the non-forest woody vegetation (NFWV). According to the examples of the United States, Canada, Russia, Ukraine, China, France and other countries, the master plan for windbreaks establishment on the Žitný Ostrov territory in southwestern part of Slovakia was elaborated. This area was 


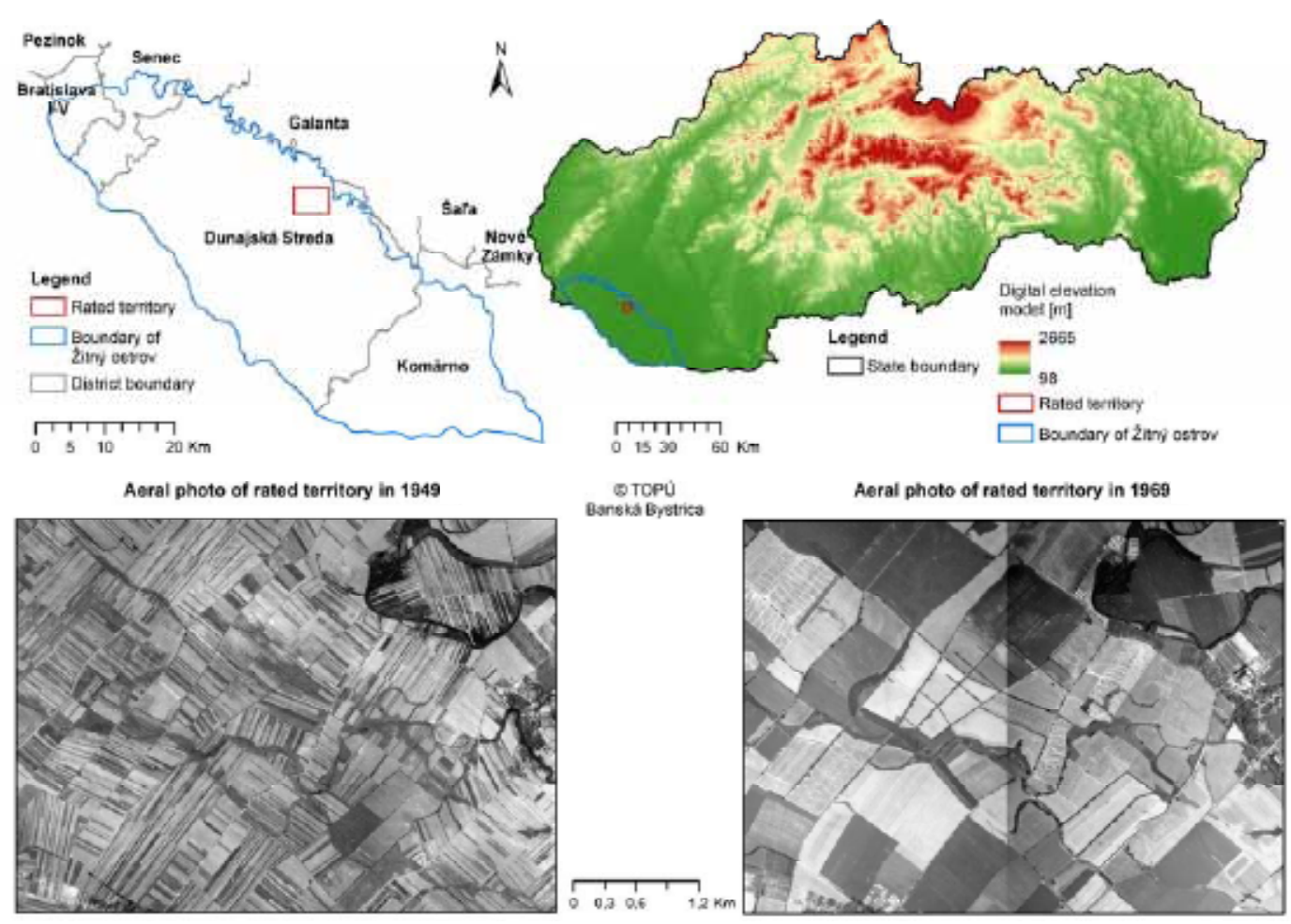

Fig. 1. Landscape structure changes at assessed landscape segment of the Žitný Ostrov territory between 1949 and 1969 time horizons. (Elaborated: Šinka 2017).

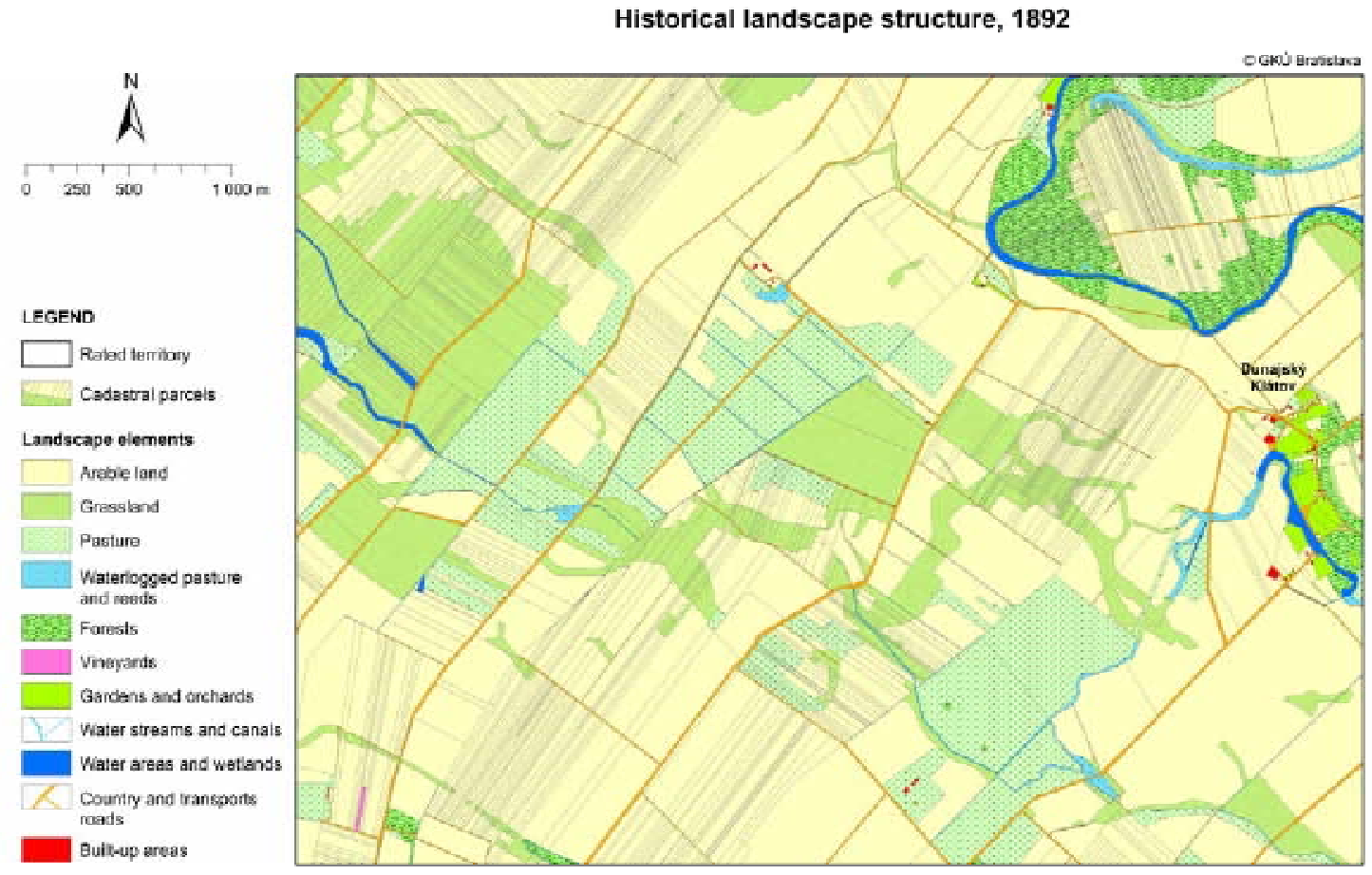

Fig. 2. Landscape structure of the assessed country segment and share of identified landscape elements in 1892. (Elaborated: Šinka 2017). 


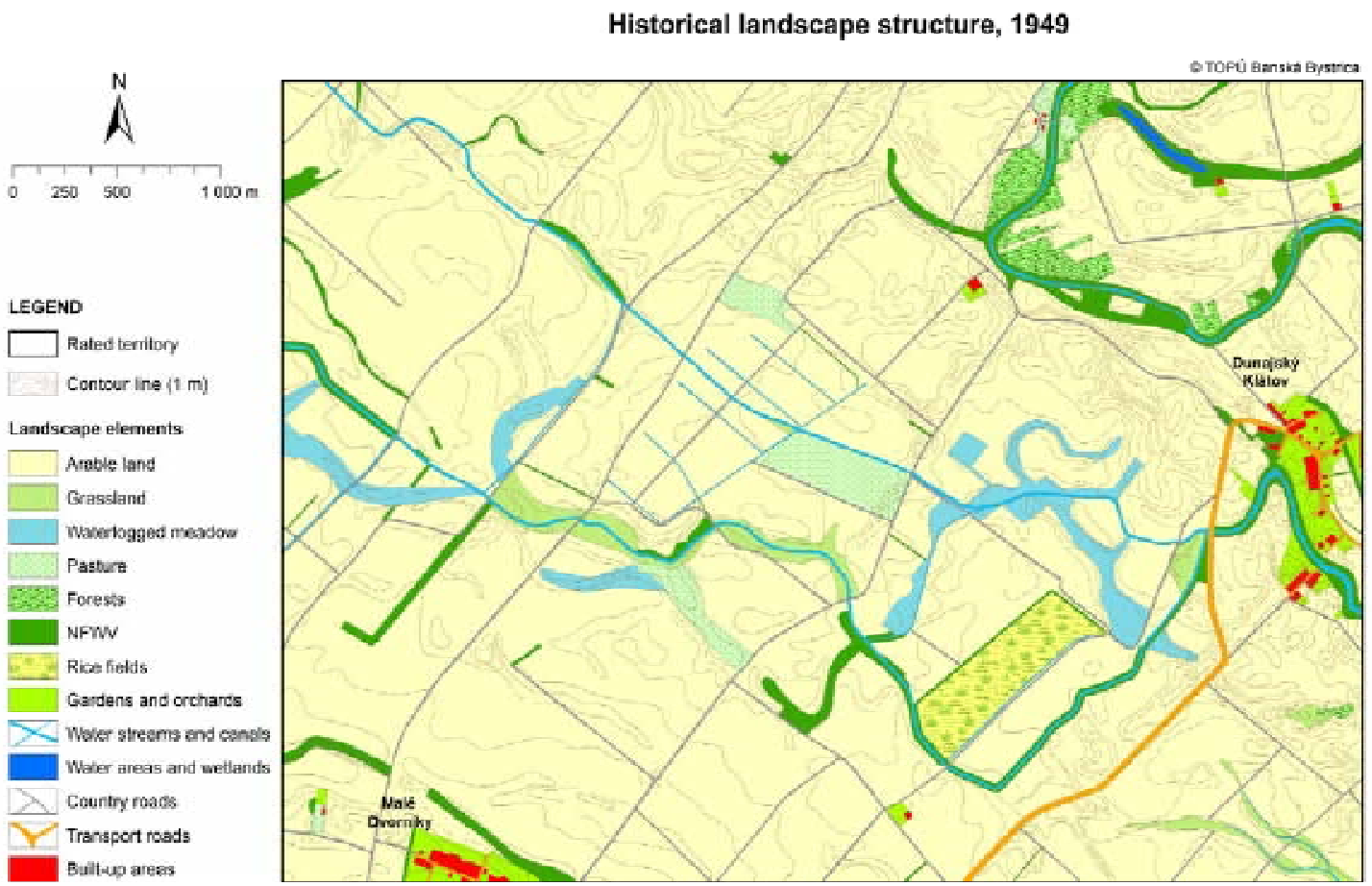

Fig. 3. Landscape structure of rated country segment and share of identified landscape elements in 1949. (Elaborated: Šinka 2017).

Historical landscape structure, 1969

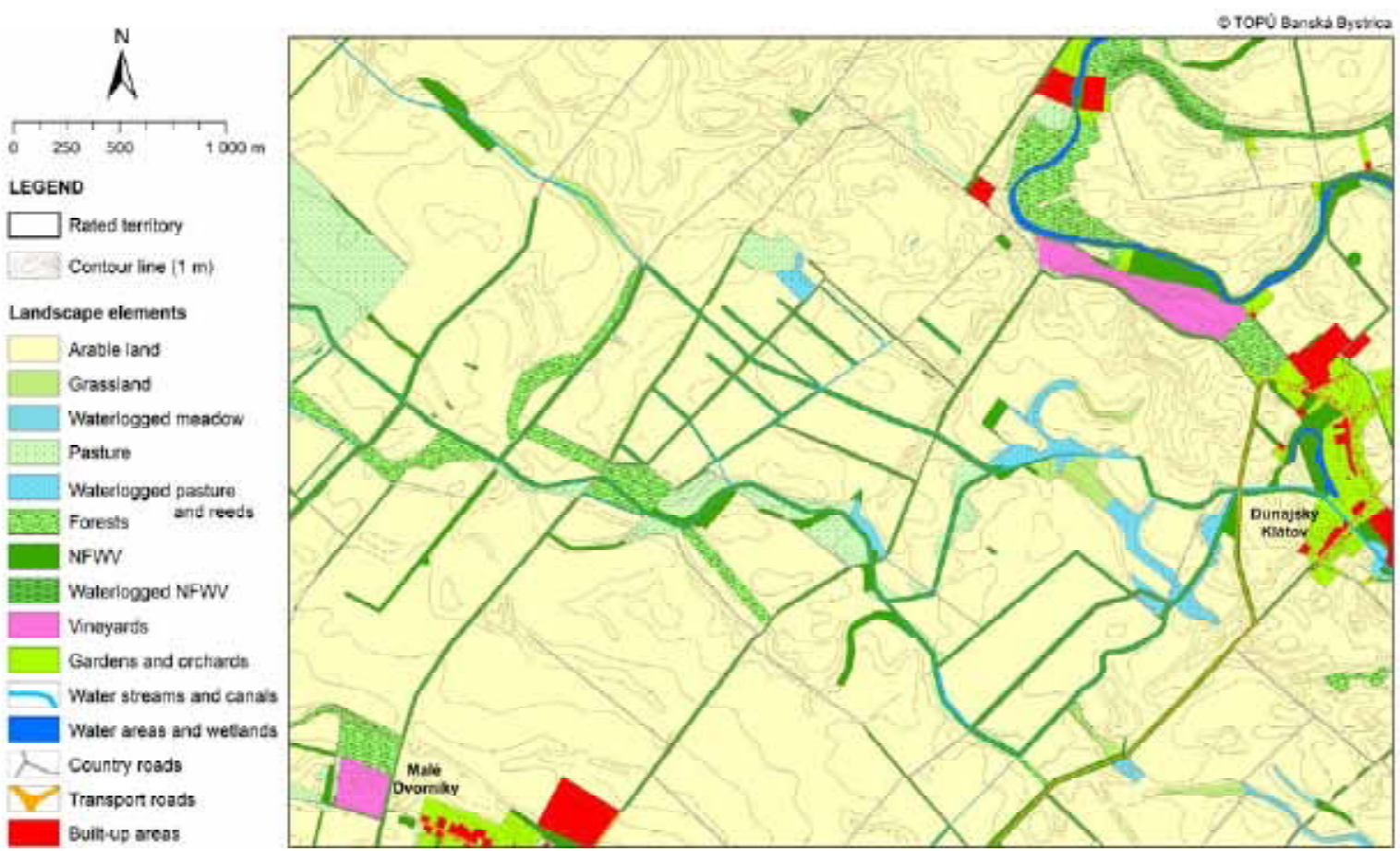

Fig. 4. Landscape structure of rated country segment and share of identified landscape elements in 1969. (Elaborated: Šinka 2017). 


\section{Contemporary landscape structure, 2017}

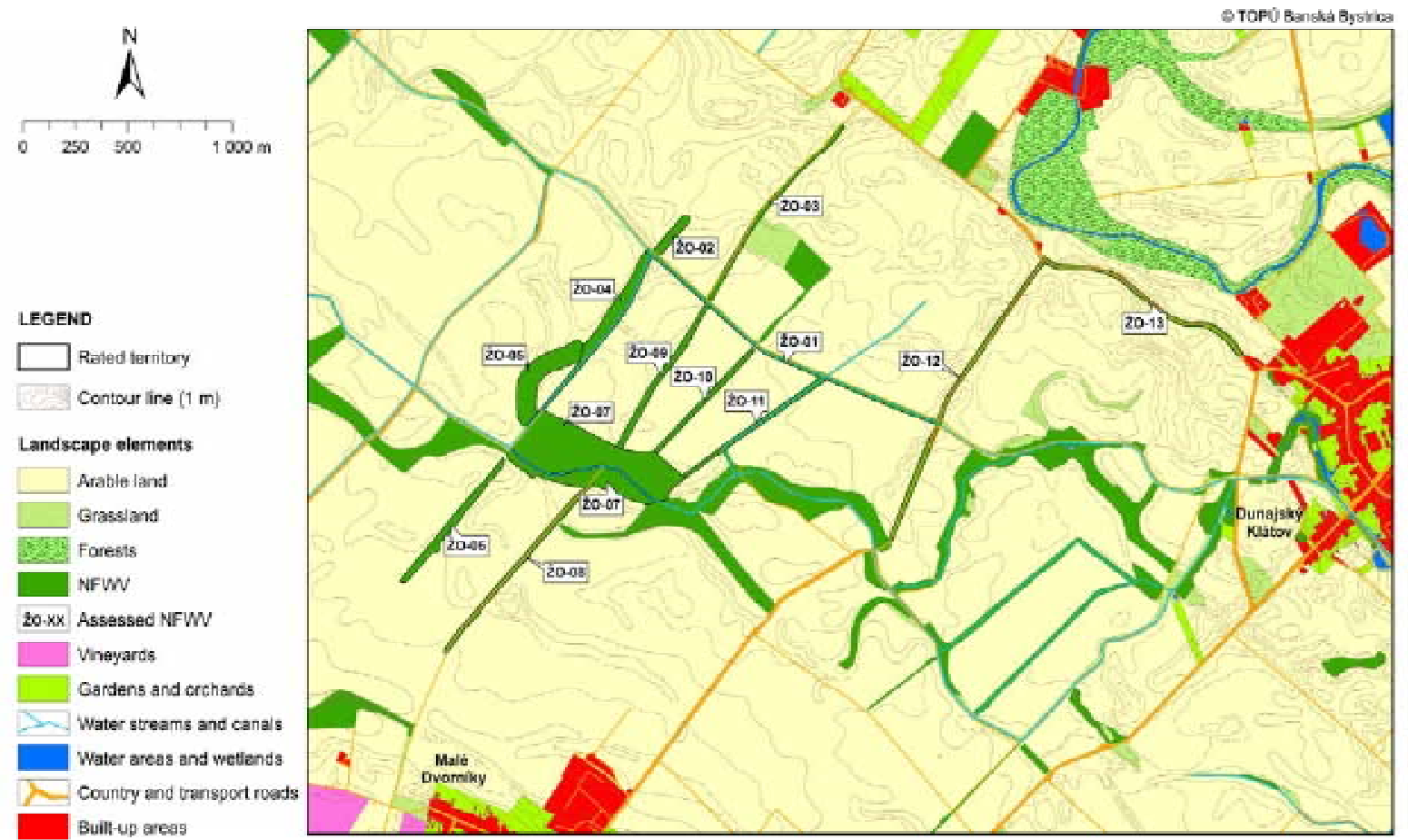

Fig. 5. Landscape structure of rated country segment and share of identified landscape elements in 2015. (Elaborated: Šinka 2017).

Table 1. Historical and contemporary landscape structure in assessed cadastral territories of the Žitný Ostrov territory at south western Slovakia.

\begin{tabular}{|c|c|c|c|c|c|c|c|c|}
\hline \multirow{2}{*}{ Landscape elements } & \multicolumn{4}{|c|}{ Area [ha] by years } & \multicolumn{4}{|c|}{ Contribution [\%] by years } \\
\hline & 1892 & 1949 & 1969 & 2015 & 1892 & 1949 & 1969 & 2015 \\
\hline Arable land & 1244.72 & 1622.39 & 1583.35 & 1586.40 & 63.25 & 82.44 & 80.45 & 80.61 \\
\hline Grassland & 306.25 & 29.14 & 11.43 & 58.34 & 15.56 & 1.48 & 0.58 & 2.96 \\
\hline Waterlogged meadow & - & 46.55 & 3.21 & - & - & 2.37 & 0.16 & - \\
\hline Pasture & 254.41 & 30.73 & 60.25 & - & 12.93 & 1.56 & 3.06 & - \\
\hline Waterlogged pasture and reeds & 13.59 & - & 17.77 & - & 0.69 & - & 0.90 & - \\
\hline Forests & 68.05 & 22.71 & 63.26 & 50.86 & 3.46 & 1.15 & 3.21 & 2.58 \\
\hline NFWV & - & 79.61 & 99.72 & 129.06 & - & 4.05 & 5.07 & 6.56 \\
\hline Waterlogged NFWV & - & - & 6.90 & - & - & - & 0.35 & - \\
\hline Vineyards & 0.39 & 24.77 RF & 18.79 & 6.34 & 0.02 & 1.26 & 0.95 & 0.32 \\
\hline Gardens and orchards & 11.32 & 24.25 & 33.32 & 31.40 & 0.58 & 1.23 & 1.69 & 1.60 \\
\hline Water streams and canals & 7.15 & 28.63 & 14.51 & 7.52 & 0.36 & 1.45 & 0.74 & 0.38 \\
\hline Water areas and wetlands & 4.38 & 2.10 & 9.11 & 10.23 & 0.88 & 0.11 & 0.46 & 0.52 \\
\hline Country roads & 1241 & 38.09 & 17.86 & & & 1.94 & 0.91 & \\
\hline Transport roads & 43.41 & 11.89 & 5.29 & 32.81 & 2.21 & 0.60 & 0.27 & 1.67 \\
\hline Built- up areas & 1.42 & 7.15 & 23.26 & 55.08 & 0.07 & 0.36 & 1.18 & 2.80 \\
\hline Sum & 1968.03 & 1968.03 & 1968.03 & 1968.03 & 100.00 & 100.00 & 100.00 & 100.00 \\
\hline
\end{tabular}

Explanation: - landscape element has not been identified, RF - rice field (see Fig. 3).

planted between 1951 and 1952 as the first territory. We have acquired the original results and conclusions that were later published in 1961 (Gemerský 1961). These results provided basic documentation for the succeeding research of chosen windbreaks from the viewpoint of woody species and spatial composition. The spacing of 60 established windbreaks on the Žitný Ostrov territory are shown on a copy of the original map (Fig. 6) and the planting scheme (Fig. 7) of the applied woody species (origin elaborated by Gemerský 1961). For windbreaks establishment 13,155 pieces of forest plant stocks were used, obtained from three arboriculture nurseries. From the nursery in Banská Štiavnica, 4,185 pieces of woody plants were acquired, in the following species composition:Acer platanoides L.,A. pseudoplatanus L., A. rubrum L., A. tataricum L., Fraxinus americana L., F. excelsior L., $F$. pubescens Lam. (F. pennsylvanica Marsh.), Ailanthus glandulosa Desf., Malus eleyi Hesse (M. domestica Borkh. 'Eleyi'), Carya ovata K. Koch, Chaenomeles lagenaria Koidz., Gleditsia triacanthos L., Chamaecyparis lawsoniana Parl., Picea pungens Engelm., Pinus nigra Arnold., Maackia amurensis Rupr., Phellodendron amurense Rupr. From the nursery in Gabčíkovo, 3,390 pieces in the following woody species were imported:Popolus x euroa- 
mericana (Dode) Guinier (P. $x$ canadensis Moench), cv. Robusta, Marilandica, Serotina, P. deltoides Marsch, P. alba L., Tilia platyphyllos Scop. From Dobor (Baka) nursery, 5,580 pieces of the following woody species were acquired: Acer negundo L., Quercus robur L., Juglans nigra L., Aesculus hippocastanum L., Alnus incana (L.) Moench, Ulmus campestris L., Prunus mahaleb L., $P$. spinosa L., Salix alba L., S. fragilis L., S. viminalis L., S. caprea L., Myricaria germanica Desv. (Tamarix germanica L.), Morus alba L., M. nigra L. Together from the three arboriculture nurseries, 13,155 pieces in 37 woody plant species were acquired and planted, from which 22 were alien species.

According to the original master plan, the plantings of woody species were applied in different compositions (Fig. 7), the windbreaks consisted of $5-7$ rows with a width span of $5-12 \mathrm{~m}$ and from 100 to $1000 \mathrm{~m}$ in length. Row spacing was $1.3 \mathrm{~m}$ on average and between woody plants in each row, there was a 1 and $2 \mathrm{~m}$ space. Considering the average exposure dates under author coordination that were planted in the assessed territory, there were almost 30 ha of windbreaks in total length of $30 \mathrm{~km}$ during 1951 and 1952. It was a small but very useful contribution for the windbreaks establishment in Slovakia, compared to the total area of planted windbreaks during the period of 1950-1964 in Bratislava region, which achieved a total of $342.22 \mathrm{ha}$, as stated by Gemerský (1961).

As presented in the published contribution, the plan- tations were experimental investigations of practice character. Therefore, different combinations of woody species were chosen in the composition and planted in the rows of windbreaks (Fig. 7). Middle rows consisted of poplars (Populus sp.) as pioneer trees, following by the objective skeleton tree species, such as native trees of the genus Acer, Quercus, Tilia. The marginal rows were planted by using coniferous and alien deciduous trees. Later, ecotone shrubby woody species were also planted. Very high number of alien woody plants was identified, representing 22 species from the total 37 species used for the windbreaks.

The most attractive and rare specimen planted was Maackia amurensis, cultivated in arboriculture nursery Banská Štiavnica, while seeds were collected from maternal trees of the Arboretum Kysihýbel. That was how this specimen was probably introduced to the open agriculture landscape in Slovakia for the first time.

\subsection{Assessment of the woody species composition on chosen windbreaks in 1976}

In 1976, the research of woody species composition and distribution on the Žitný Ostrov territory was conducted prior to the construction of the Danube water dump. A list of investigated woody species in the windbreaks of defined territory is shown in the Table 2 (surveyed and documented by Supuka; in Benčat' et al. 1984). From the

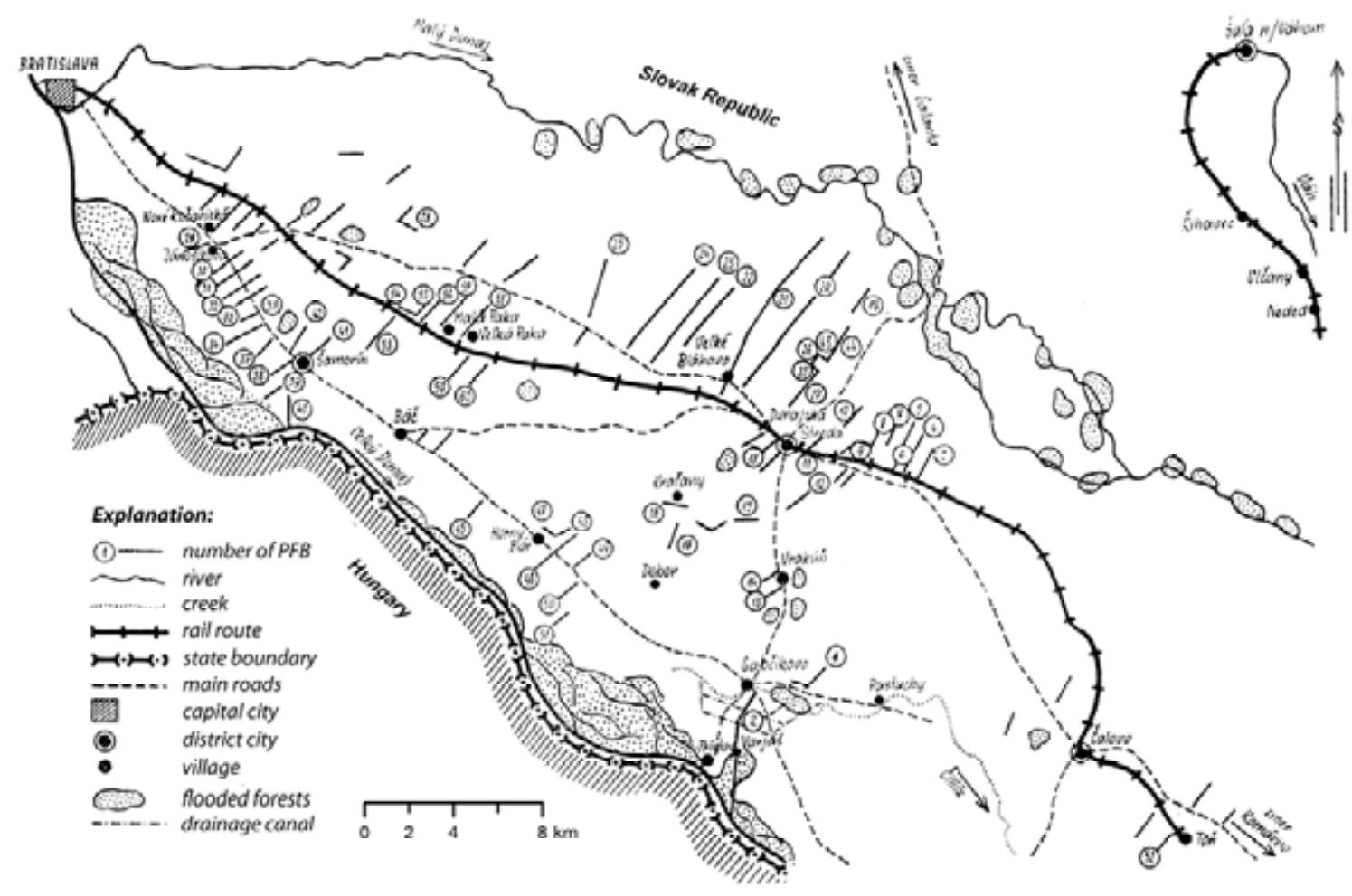

Fig. 6. Distribution of 60 planned protective forest belts (PFB) at the Žitný Ostrov territory, South- Western part of Slovakia. Original scheme has drawn by Gemerský (1961). (Adjusted by Šinka \& Supuka 2016). 


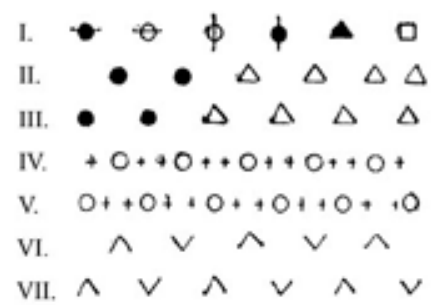

c

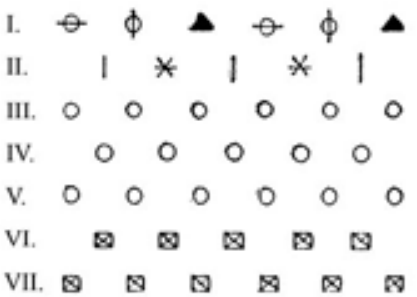

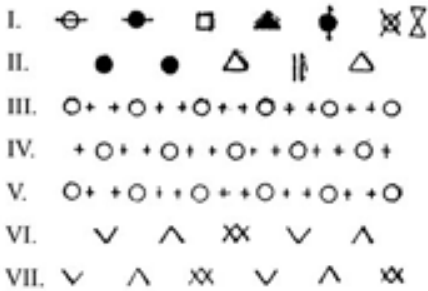

d
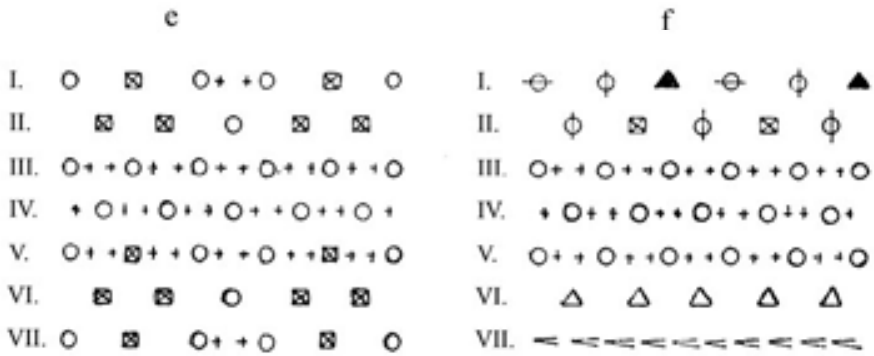

Indication of woody species

$\triangle$ Acer spp.

II Aesculus hippocasslamum

- Robinia pseudoacacia

I Alnus incana

- Carya ovata

- Fraximus spp.

$\Theta$ Gleditschia triancanthos

Chaenomeles lagenaria
$\propto$ Chamaecyparis lawsoniana
- Juglans nigra
$\square$ Maackia amurensis
* Morus eleyi
$\varnothing$ Phellodendron amurense

$\checkmark$ Picea pungens

$\wedge$ Pinus nigra

○ Populus spp.

$\phi$ Prunus spp.

+ Quercus robur

凶 Salix spp.

$\bowtie$ Tilia platyphyllos

Fig. 7. Distribution of woody plant species in planting model plots (a-b) and rows (I.-VII.) in the protective forest belts (PFB). Original scheme has been drawn by Gemerský (1961) (Adjusted by Šinka and Supuka 2016).

total number of 19 assessed windbreaks, 12 of them were identified as identical to windbreaks founded in 19511952 (No. 23, 25, 26, 28, 29, 30, 31, 32, 33, 34; in Fig. 6). Concerning spatial characteristics, the windbreaks have reached $5,10,15$ and $20 \mathrm{~m}$ in width and an average of 7 to $15 \mathrm{~m}$ in height during the past 25 years. Among the 28 inventoried woody species, 12 of them were alien. Windbreaks have achieved different density depending on the applied woody species and the number of planted rows or width of forest belt. They had $70-90 \%$ tree crown canopy or stand density. In wider windbreaks (15 - 20 $\mathrm{m}$ in width), auto-regeneration processes were identified when a new woody species generation appeared because of natural successive processes, disseminated by wind or animal vectors.

There were certain differences between the woody species composition in the assessed periods. In 1976, neither coniferous nor deciduous woody species such as Carya ovata, Chaenomeles lagenaria, Maackia amurensis, Phellodendron amurense, Myricaria germanica were found. The reason might lie in the allocation of the above mentioned woody species to other than inspected and inventoried windbreaks. The plants died due to drought, water flooding, game nibbling or mechanical 
damages. There was a high probability that when surveying the windbreaks in 1976, there were incorrect woody species identified, e.g. poplar hybrids, North American ashes, and rare Maackia amurensis and Phelodendron amurense. In the case of Maackia amurensis, there was probably an identification mistake and the trees were inventoried as Caragana arborescens in 1976 (see Table 2). When a direct comparison of the woody species composition between the time horizons of 1952 and 1976 was made, the investigated windbreaks were very problem- atic. Original planting projects from 1951-1952 were inaccessible or could not be found. The projects were probably not elaborated for each windbreak separately and planting was provided per a published variable model scheme (Fig. 7).

The state of woody species composition on the Žitný Ostrov territory windbreaks looked very rich in 1976. On the one hand, it creates a variable and rare woody species gene pool; on the other hand, it is an important food source and spatial habitat for supporting animal biodi-

Table 2. Woody species composition in chosen windbreaks at Žitný Ostrov territory in 1976.

\begin{tabular}{|c|c|c|c|c|c|c|c|c|c|c|c|c|c|c|c|c|c|c|c|c|}
\hline \multirow{2}{*}{ Tree species layer } & \multicolumn{20}{|c|}{ Register number of assessed windbreak } \\
\hline & 23 & 25 & 26 & 27 & 28 & 29 & 30 & 31 & 32 & 33 & 34 & 35 & 91 & 92 & 93 & 94 & 95 & $95 a$ & 96 & \\
\hline Acer campestre L. & & + & + & & & & & & & & & & & & & & & & & 2 \\
\hline Acer platanoides $\mathrm{L}$ & & & + & & + & + & + & & & & + & & & & & & & & + & 6 \\
\hline Ailanthus altissima (Mill.) Swingle & & + & & & & & & & & & & & + & + & + & & & & & 4 \\
\hline Caragana arborescens Lam. & & & & + & & & & & & & & & & & & + & & & & 2 \\
\hline Crataegus laevigata (Poir) DC & & & + & & & & + & + & + & + & & + & & & + & & + & & & 8 \\
\hline Euonymus europaeus L. & & + & + & & + & + & & + & & & & & & & + & & & & + & 7 \\
\hline Fraxinus excelsior $\mathrm{L}$. & & + & + & & & + & & & & & + & + & + & & & + & & & & 7 \\
\hline Gleditsia triacanthos $\mathrm{L}$. & & & + & & & & & & & & & & & & & & & & & 1 \\
\hline Juglans nigra L. & & & & & & & & & & & & + & & & & + & & & & 2 \\
\hline Juglans regia L. & & & & & & & & & & & & & + & + & & & & & & 2 \\
\hline Lonicera tatarica L. & & & & & & & & & & & & & & & & + & & & + & 2 \\
\hline Ligustrum vulgare L. & & & + & & & + & & & & & + & & & & & + & & & + & 5 \\
\hline Morus alba L. & & & & & & & + & + & & & & & & & & & & & & 2 \\
\hline Negundo aceroides Moench. & + & + & + & & + & & + & + & & & + & + & + & + & + & + & & & + & 13 \\
\hline Populus alba L & & & & & & & & & & & & & & & & & & + & & 1 \\
\hline Populus $\mathrm{x}$ canadensis Moench. & + & & & + & & & + & + & + & + & + & + & & + & + & & + & & & 11 \\
\hline Quercus robur $\mathrm{L}$. & & & & & + & & & & & & & & & & & + & & & + & 3 \\
\hline Rhamnus catharticus L. & & & & & & & & & & & & & & & + & + & & & & 2 \\
\hline Robinia pseudoacacia L. & + & + & + & & + & + & + & + & + & + & & & & & & + & & + & + & 12 \\
\hline Rosa canina L. & + & + & + & + & + & & + & + & & + & + & & + & & + & + & + & + & + & 15 \\
\hline Rubus fruiticosus $\mathrm{L}$. & & & + & & & & & & + & & & & + & & & & & & & 3 \\
\hline Salix alba L. & & & & & & & & & & & & & & & & & & + & & 1 \\
\hline Sambucus nigra L. & + & + & & + & + & + & & + & + & + & + & & + & + & + & & + & & & 13 \\
\hline Sophora japonica & & & & & + & & & & & & & & & & & & & & & 1 \\
\hline Swida sanguinea (L.) Opiz. & + & + & + & & & & & & & & & & & & & + & & + & + & 6 \\
\hline Syringa vulgaris $\mathrm{L}$. & & + & + & & & & & & & & & & & & & + & & & + & 4 \\
\hline Ulmus carpinifolia Gled. Non Borkh. & + & + & + & & + & + & + & & & & & & + & & & + & & & & 8 \\
\hline Viburnum opulus L. & & + & & & & & & & & & & & & & & & & & + & 2 \\
\hline Species biodiversity in windbreaks & 7 & 12 & 14 & 4 & 9 & 7 & 8 & 8 & 5 & 5 & 6 & 6 & 8 & 5 & 8 & 13 & 4 & 5 & 12 & \\
\hline
\end{tabular}

Explanation: + occured woody species in relevant windbreak.

versity. However, many alien woody species are currently considered as very invasive.

\subsection{Assessment of woody species composition on chosen windbreaks in 2015}

In 2015 we focused our research on the development of the landscape structure changes through four time horizons with regards to the share of NFWV on chosen landscape segments. Those results are described in the previous chapter. The distribution of surveyed woody vegetation formations is shown in Fig. 5. There is a real correspondence between surveyed windbreaks in 1967 and 2015, specifically in the windbreaks No. 26, 27, 35 (in 1976) and ŽO-3, ŽO-9 (in 2015). The frequency of appearance of woody species in surveyed windbreaks from $\check{Z} \mathrm{O}-1$ till $\breve{\mathrm{O}}-13$ is given in Table 3 . Overall, there were 27 deciduous woody species identified in the tree layer and 12 species in the shrubby layer. Nine of them
(9) were alien tree species. Four alochtonous species should be considered with high potential in invasive growth manifestation, as are Ailanthus altissima (Mill.) Swingle, Fraxinus americana L., Negundo aceroides Moench., Robinia pseudoacacia L. The above noted species are remnants from the first plantings, since they were found in the list of species planted in 1951-1952 and were also surveyed in 1976. All the mentioned trees have high auto-regeneration abilities at stands because of their invasive manifestation. A high percentage of the trees were identified as other alien trees, Populus $x$ canadensis (Aiton) Smith and Populus nigra L.' Italica'. Both species belong to traditional tree species applied in windbreaks on rated landscape segment of south-western Slovakia and have survived up to the present. Unfortunately, these alien tree species are dominant in the windbreaks. From native trees, Populus nigra L., Fraxinus excelsior L. and Salix fragilis L are dominant. Concerning shrubby layer, all the inventoried species are of native origin. The char- 
acteristics of the woody species in surveyed windbreaks are presented in Table 3 per tree and shrubby layers and percentage of abundance. In some windbreaks, a minimum of 9 woody species and a maximum of 18 species were identified (found in ŽO-4). As a part of the field research, we focused our attention on the inventory of oversized and old trees rather than native trees as gene pool resources. The species surveyed were e.g. Populus alba $\mathrm{L} .\left(\mathrm{d}_{13}=73 \mathrm{~cm}\right.$, tree height $=30 \mathrm{~m}$, crown width $=25$ $\mathrm{m})$, Salix fragilis L. $(140 \mathrm{~cm} / 32 \mathrm{~m} / 28 \mathrm{~m})$, Populus nigra L. $(91 \mathrm{~cm} / 35 \mathrm{~m} / 30 \mathrm{~m})$, Quercus robur $\mathrm{L}$. $(92 \mathrm{~cm} / 33 \mathrm{~m} / 16$ $\mathrm{m})$. The estimated age of trees is about 150 years old.

\subsection{Assessment of the woody species synantropisation in NFWV surveyed in 1976 and 2015}

According to the method stated in chapter 2, the index synantropisation was calculated for each windbreak surveyed in 1976 and 2015. Calculated values theoretically reached within span of $0.0-1.0$. Afterwards, three score groups in synantropisation level were stated: a) low level $\leq 0.25$; moderate level $-0.26-0.49$; high level $\geq 0.50$. On assessed of 19 NFWV in 1976 (Table 2) the distribution according to achieved synantropisation indexes is follow: low level - 4 NFWV (windbreaks No. 95, 95a), moderate -12 NFWV (No. 23, 25, 26, 28, 29, 32, 33, 34, 91, 93, 94, 96), high level - 5 NFWV (No.27, 30, 31, 35, 92). In 2015 the synantropisation indexes on assessed 13 NFWV (Table 3) were as follow: low level - $8 \mathrm{NFWV}$ (windbreaks and other line forms, No. 1, 2, 4, 5, 6, 10, 11, 12), moderate level - 5 NFWV (No. 3, 7, 8, 9, 13), high level - 0 NFWV. While surveying the NFWV in 2015 more specific mapping method was used, taking into account cover abundance in reléves. In spite of lower indexes, the results show high cover and dominance of many alien trees in NFWV, such as Populus $x$ canadensis, Robinia pseudoacacia, Prunus cerasifera, Negundo aceroides. Less share has Ailanthus altissima, but in high invasive growth manifestation. These alien trees determinate landscape character in many cases. In many cases, we could observe occurrence of the fruit trees, e.g. Juglans regia, Malus domestica, Pyrus communis, Morus alba, which also support biodiversity.

Table 3. Woody species composition in chosen windbreaks at Žitný Ostrov territory in 2015.

\begin{tabular}{|c|c|c|c|c|c|c|c|c|c|c|c|c|c|}
\hline \multirow{2}{*}{ Tree species layer } & \multicolumn{13}{|c|}{ Occurrence of woody species in \% according to set number of NFWV } \\
\hline & 1 & 2 & 3 & 4 & 5 & 6 & 7 & 8 & 9 & 10 & 11 & 12 & 13 \\
\hline Acer campestre L. & & & & 15 & & & & & & & & & \\
\hline Acer platanoides $\mathrm{L}$ & & & & 5 & & & & & & & & & \\
\hline Acerpseudoplatanus $\mathrm{L}$ & 5 & & & 5 & & 20 & & & & & & & \\
\hline Acerpseudoplatanus L. 'Atropurpureum' & 10 & & & & & & & & & & & & \\
\hline Ailanthus altissima (Mill.) Swingle & & & & & & & & & & & & & 30 \\
\hline Celtis occidentalis L. & & & & & & & + & & & & & & \\
\hline Cerasus avium (L.) Moench & 5 & & & & & & & & & & & & \\
\hline Fraxinus americana $\mathrm{L}$. & & & & & & & & 5 & & & & & \\
\hline Fraxinus angustifolia Vahl. & & & & 55 & & & & & & & 15 & & \\
\hline Fraxinus excelsior $\mathrm{L}$. & & & & + & 5 & & 10 & 10 & & & 10 & 10 & 10 \\
\hline Juglans regia $\mathrm{L}$. & & & & & & & 5 & 10 & 5 & & 5 & 30 & 20 \\
\hline Malus domestica Borkh. & + & & & & & & & & & & & & \\
\hline Negundo aceroides Moench. & & & & & & 40 & & & & & & & \\
\hline Populus alba L. & 5 & & & + & & & 5 & & 10 & 35 & 10 & & \\
\hline Populus $x$ canadensis Moench. & 55 & & 30 & 10 & 85 & 10 & 60 & 10 & 20 & & & & \\
\hline Populus $x$ canescens (Aiton) Smith. & 10 & & & & & & & & 5 & & 10 & & \\
\hline Populus nigra L. & + & & 10 & + & & 10 & & 35 & 20 & 25 & 15 & & \\
\hline Populus nigra L. 'Italica' & & & & & & & & & + & & 5 & & \\
\hline Prunus cerasifera Ehrh. & + & 5 & 20 & & 5 & & & & 10 & + & 15 & 10 & \\
\hline Prunus padus $\mathrm{L}$. & & & & & & & 10 & & & 20 & 5 & & \\
\hline Pyrus communis $\mathrm{L}$. & & & & & & & & & & & & + & \\
\hline Quercus robur $\mathrm{L}$. & & & & & & + & & & & & + & & \\
\hline Robinia pseudoacacia L. & 5 & 90 & 10 & 5 & + & 10 & & 10 & 10 & & & 40 & 40 \\
\hline Salix alba L. & & & & & & & & & 10 & & & & \\
\hline Salix caprea L. & 5 & & & 5 & & & & & & & & & \\
\hline Salix cinerea L. & 5 & & & + & & & & & & & & & \\
\hline Salix fragilis L. & 5 & & 30 & & 5 & 10 & 10 & 20 & 10 & 20 & 10 & 10 & \\
\hline Shrubby species layer & 1 & 2 & 3 & 4 & 5 & 6 & 7 & 8 & 9 & 10 & 11 & 12 & 13 \\
\hline Crataegus laevigata(Poir.) DC & 55 & 5 & 20 & 20 & 20 & 15 & & 15 & 10 & & & 40 & 30 \\
\hline Euonymus europaeus L. & & 5 & & & 5 & 10 & & 5 & 10 & & & 5 & \\
\hline Frangula alnus Mill. & 5 & & 10 & 20 & 15 & 10 & 15 & 10 & & & 5 & & \\
\hline Ligustrum vulgare L. & 5 & & & & & & & 5 & & & + & & \\
\hline Prunus insititia Juls. & + & 5 & & + & & & & & + & 10 & + & & \\
\hline Prunus spinosa L. & 5 & & 20 & 10 & 10 & & 30 & & & & & 10 & 30 \\
\hline Rhamnus catharticus $\mathrm{L}$. & 5 & 5 & 20 & 10 & 10 & 10 & & 10 & & 10 & 10 & & \\
\hline Rosa canina L. & 5 & 5 & 20 & & & 15 & & & 10 & 5 & 5 & + & 10 \\
\hline Salix viminalis $\mathrm{L}$. & + & & & & & & & & & & & & \\
\hline Sambucus nigra L. & + & 70 & 10 & 20 & 20 & 40 & 35 & 15 & 20 & 10 & 5 & 10 & 30 \\
\hline Swida sanguinea (L.) Qpiz. & 10 & 10 & & 20 & 20 & & 20 & 30 & 50 & 65 & 70 & 35 & \\
\hline Viburnum opulus L. & 5 & & & & & & & 10 & & & 5 & & \\
\hline
\end{tabular}

Explanation: 20-percentage of the occurrence, + less than $5 \%$ occurrence. 


\section{Discussion}

Agricultural and forest landscapes show distinct footprints of development and alternative structural changes, as was assessed in ten countries of the Carpathian region in the Eastern and Central Europe, including Slovakia, over the past 250 years (Munteanu et al. 2014). There are several published sources in the Eastern Europe countries, such as Slovakia and Czech Republic that have documented expressive landscape changes caused by consolidation and intensification of agriculture (Salašová 2001; Supuka et al. 2008; Lipský et al. 2011; Štefunková et al. 2011 and others). Although this socioeconomic process does not apply for example to western European countries, their landscape structure changes are distinct due to mainly industrialization and intensification of agriculture technologies at the advanced farms, e.g. in France, Germany, England, but also in the United States and Canada (Insley 1988; Soltner 1991). In these countries, arable land share has increased and permanent grasslands decreased, which is similar to our region. In order to obtain new agriculture land, deforestation reached its maximum in the 19th century. In many localities, this trend has been continuing until the present day, e.g. in the Amazonian rain forest. Removal of natural ecosystems and valuable habitats, adjustment of natural water streams, and arrangement of new water irrigation nets were already known in Egypt, China and Middle East historical territories. The level of scientific knowledge in natural sciences was reflected in the establishment of windbreaks at the beginning of 20th century, firstly in the Western and later in Eastern countries (the United States, Canada, France, Russia, China, and former Czechoslovakia). Those were expressive and positive contributions for strengthening the land protection, ecological stability and landscape architectural values; in new scientific terms defined as ecosystem services (Reyers et al. 2009; Lampartová et al. 2015).

At the time of spontaneous establishment of new anthropogenic woody line vegetation, a number of alien species were planted. Many of those showed high adaptability level, auto-reproduction and domestication manifestation currently called invasive with negative destruction effects to natural biodiversity. To this category belong e.g. Robinia pseudoacacia L., Ailanthus altissima (Mill.) Swingle and Negundo aceroides Moench, very often surveyed in studied windbreaks of Slovakia and in other European countries (Soltner 1991; Supuka et al. 2013 and others). Elimination of the alien invasive plants is currentlyvery problematic both technically and biologically. On the one hand, old and oversized native trees and cultural fruit species create a considerable cultural gene pool (Paganová \& Bakay 2010; Supuka \& Pucherová 2013; Verešová \& Supuka 2013). On the other hand, in scattered woody vegetation a number of plant taxonomy issues or identification of species has occurred. Varieties of the genus Prunus are very often part of NFWV ele- ments in agriculture landscape (Baranec et al. 2011). In historical agriculture landscape structure on upland of Slovakia, mostly shrubby species between plots on the borders and terraces were surveyed (Špulerová et al. 2017).

In many cases, the line form of NFWV is pruned and shaped as hedges especially in Western countries, e.g. in Austria (Kurz et al. 2011), France or England (Soltner 1991). These formations create uniform landscape networks with low visual value and a low potential for use as a wild life habitat. Low shares of line form NFWV and natural habitats in agriculture landscape are considered as a negative factor (Salašová 2001; Supuka et al. 2013; Demková \& Lipský 2017). Contemporary share of NFWV is generally low, reaching $3-10 \%$ on average (Insley 1988; Pucherová 2004; Supuka et al. 2013; Kuczman 2014). There are attempts to establish an EU Foundation for new elements within the framework of European Agriculture Policy (EAP) in order to increase the share to $8-12 \%$.

\section{Conclusions}

The land cover changes on Žitný Ostrov territory were assessed within the rated periods of 1892, 1949, 1969, and 2015. The landscape elements, pasture, grassland, waterlogged meadows and wetlands were found at a rapid decrease in area share from $29 \%$ land cover in 1892 to $2.96 \%$ in 2015 . This caused a decrease in ecological stability and biodiversity. In the same period, arable land has increased by $17 \%$ and built-up areas by $2.7 \%$. Amelioration of natural water areas and wetlands was also caused by the construction of water drainage canals used for irrigation system. Small mosaic plots were altered as large cultural plots increased between 1949 and 1969.

The investigation of NFWV started by examining the original planting schemes and the list of applied woody species in the new established windbreaks from period of 1951-1952. Unfortunately, planting projects for protective forest belts were not found. More than 13 thousand pieces in 37 woody species, including 22 alien species, were received and planted from three arboriculture nurseries. In the assessed territory, almost 30 ha of windbreaks in total length $30 \mathrm{~km}$ were established. Many applied alien woody species were attractive in that time, e.g. Maackia amurensis, Phellodendron amurence, Morus alba Gleditsia triacanthos, or from the group of coniferous, e.g. Chamaecyparis lawsoniana, Picea pungens, Pinus nigra. In 1967, from total number of 19 assessed windbreaks, 12 were identified as identical to windbreaks planted in 1951-1952. Currently, 28 woody species were identified, including 12 alien ones. Therefore, there are less woody species today than in 1952. In 2015 the research focused on the development of landscape structure changes through four time horizons with regards to the share of NFWV in the chosen 
landscape segment. Thirteen windbreaks were surveyed, while real coincidences between 1967 and 2015 were at three windbreaks No. 26, 27, 35 (in 1976) and ŽO-3, ŽO-9 (in 2015). At all windbreaks, 27 deciduous woody species in tree layers were identified, including 9 alien species. Four alochtonous species should be considered with high potential in invasive growth manifestation as are Ailanthus altissima, Fraxinus americana, Negundo aceroides, and Robinia pseudoacacia. These woody species are mostly remnants from the first plantings, because they were found in the list planted in 1951-1952 and were surveyed in 1976 and again in 2015. There were many oversized and old native trees surveyed, representing rare gene pool resources.

The assessed windbreaks at Žitný Ostrov territory need woody species and spatial reconstruction. Due to their density, thinning of the trees is necessary in order to enable crown size growth and stability. It is recommended to remove dead and strongly damaged trees and leave some native trees with cavities for supporting bird and insect diversity. Gradually, the above mentioned invasive tree species should be removed and replaced by native species of the genus Acer, Carpinus, Cerasus, Fraxinus, Padus, Populus, Pyrus, Quercus, Salix, Tilia and Ulmus. Large gaps in windbreaks should be planted by a new tree species, in ecotones by native shrubs.

\section{Acknowledgements}

This contribution was prepared within the grant projects of the Ministry of Education, Science, Research and Sport of the Slovak Republic, project VEGA No. 1/0044/2017 and KEGA No. 001SPU-4/2017.

\section{References}

Agnoletti, M. [ed.] et al., 2010: Paesaggi rurali storici. Roma-Bari, Laterza et Figli, 566 p.

Baranec, T., Žgančíková, I., Muráňová, K., 2011: Preliminary results of study of the taxonomical and morphological variability of the genus Prunus L. in the biocorridors of the agricultural landscape on the territory of SW Slovakia. Acta Průhoniciana, 99:97-101.

Benčat', F., Požgaj, J., Mercel, F., Supuka J. et al., 1984: Rozšírenie drevín v záujmovom území Dunajského diela. Acta Dendrobiologica, 6/84. Bratislava, VEDA SAV, 164 p.

Cieszewska, A., Drexler, D., Bihuňová, M., Kalincsák, P., Belova, O., Procházka, J., 2010: Eastern Region: Chapter 6. In: Management of recreation and nature based tourism in European forests. Berlin Heidelberg, Springer-Verlag, p. 115-139.

Demková, K., Lipský, Z., 2017: Comparison of the current state of non-forest woody vegetation in two contrasted case study areas in Central Europe. Moravian Geographical Reports, 25:24-33.
Fanneng, H. E., Meijiao, L. I., Schicheng, L. I., Ran, X., 2015: Comparison of changes in land use and land cover in China and the USA over the past 300 years. Journal of Geography Science, 25:1045-1057.

Gemerský, V., 1961: Skúsenosti s ochrannými lesnými pásmi na Žitnom ostrove. Vedecké práce VÚLH v Banskej Štiavnici, No. 2, Bratislava, SAV, p. 153228.

Hernik, J. (ed.), 2009: Cultural landscape-across disciplines. Krakow, Branta, 365 p.

Insley, H. (ed.), 1988. Farm Woodland Planning. London, Forestry Commission, Bulletin, 80, 142 p.

Jurko, A., 1990: Ekologické a socioekonomické hodnotenie vegetácie. Bratislava, VEDA SAV, 200 p.

Kuczman, G., 2014: Landscape structure and biodiversity of woody plants in the cadastral territory of Kolinany. Journal of Environmental Protection, Safety, Education and Management, 2:25-32.

Kuča, K. (ed.) et al., 2015: Krajinné památkové zóny. Praha, NPÚ, 512 p.

Kupka, J., 2010: Krajiny kulturní a historické. Praha, ČVUT, 180 p.

Kurz, P., Machatschek, M., Iglhauser, B., 2011: Hecken. Geschichte und Ökologie Anlage. Erhaltung und Nutzung. Graz, Stuttgart, Leopold Stocker Verlag, $440 \mathrm{p}$.

Lampartová, I., Schneider, J., Vyskot, I., Rajnoch, M., Litschmann, T., 2015: Impact of protective shelterbelt microclimate characteristics. Ekológia (Bratislava), 34:101-110.

Lipský, Z., Demková, K., Skaloš, J., Kukla, P., 2011: The influence of natural conditions on changes in landscape use: a case study of the Lower Podoubraví region (Czech Republic). Ekológia (Bratislava), 30:239-256.

Morton, A., 1998: Tree heritage of Britain and Ireland. Shrewsbury, Swan Hill Press, 208 p.

Munteanu, C., Kuemmerle, T., Boltiziar, M. et al., 2014: Forest and agricultural land changes in the Carpathian region - A meta-analyses of long-term patterns and drivers of change. Land Use Policy, 38:685-697.

Paganová, V., Bakay, L., 2010: Biologickévlastnostijarabiny oskorušovej Sorbus aucuparia L. v meniacich sa podmienkach prostredia. Nitra, VES SPU, $92 \mathrm{p}$.

Petit, C., Konold, W., Höchtl, F., 2012: Historic terraced vineyards: impressive witness of vernacular architecture. Landscape History, 33:5-28.

Pucherová, Z., 2004: Vývoj využitia krajiny na rozhraní Zobora a Žitavskej pahorkatiny. Nitra, FPV UKF, Edícia Prírodovedec, 147 p.

Reyers, B., O’Farrell, P., Cowling, R. M., Egoh, D., Le Maitre, D. C., Vlok, J. H. J., 2009: Ecosystem Services, Land-Cover Change and Stake holders: Finding of Sustainable Foodhold for Semiarid Biodiversity Hotspot. Ecology and Society, 14:38. 
Salašová, A., 2001: Krajinárske zásady obnovy drevinových vegetačných prvkovv krajine In: Obnova plošné a bodové zeleně v krajině. Brno, MENDELU, p. 18-22.

Soltner, D., 1991: L'arbre et la haie. Angers, Collection Sciences et Techniques Agricoles, 203 p.

Supuka, J., Verešová, M, Šinka, K., 2011: Development of vineyards landscape structure with regard to historical and cultural values. Ekológia (Bratislava), 30:229-238.

Supuka, J., Pucherová, Z., 2013: Changes in landscape structure and gene pool importance woody plants in the Žirany cadastre, Slovakia. Folia Oecologica, 40:107-116.

Supuka, J., Šinka, K., Pucherová, Z., Verešová M., Feriancová, L., Bihuňová, M., Kuczman, G., 2013: Landscape structure and biodiversity of woody plants in the agricultural landscape. Folia Universitatis Agriculturae et Silviculturae Mendelianae Brunensis, Monographic series, Vol.VI, Issue 9. Brno, Mendel University in Brno, 187 p.

Špulerová, J., Dobrovodská, M., Lieskovský, J., Bača, A., Halabuk, A., Kohút, T. et al., 2011: Inventory and classification of historical structures of the agricultural landscape in Slovakia. Ekológia (Bratislava), 30:157-170.
Špulerová, J., Dobrovodská, M., Šatalová, B., Kanka, R., 2017: Small woodlands and trees in traditional agriculture landscapes of Slovakia. Journal of Landscape Ecology, 10:1-15.

Štefunková, D., Dobrovodská, M., Kanka, R., Krnáčová, Z. et al., 2011: Atraktivita malokarpatskej krajiny s dôrazom na historické agrárne štruktúry a biodiverzitu. Bratislava, ÚKE SAV, 200 p.

Tetera, V., Boček, S., Jongepierová, I., Krška, B., Němec, J., Pešek, R. et al., 2006: Ovoce Bílých Karpat. Veselí nad Moravou, KATOS CZ, 310 p.

Tóth, A., Kuczman, G., Feriancová, L., 2016: Species composition and diversity of non-forest woody vegetation along roads in the agricultural landscape. Lesnícky časopis - Forestry Journal, 62:56-66.

Tutka, J., 2010: Funkcie lesov v pol'nohospodárskej krajine. In: Quo vadis lesníctvo? Zvolen, NLC, p. 222-233.

Verešová, M., 2011: Krajinno-architektonické hodnoty vinohradníckych lokalít Západného Slovenska. Dizertačná práca. Nitra, SPU, 95 p.

Verešová, M., Supuka, J., 2013: Changes of landscape structure and cultural values of vineyard landscape. Acta Universitatis Agriculturae et Silviculturae Mendelianae Brunensis, 61:1459-1470.

Zrníková, K., Jakubec, B., Modranský, J., 2014: Structure of woody plants composition of agricultural landscape structure focusing on the genetic resources of fruit trees in selected cadastral area. Acta Facultatis Ecologiae, 30:49-62. 